\title{
Excessive nutrients select for dinoflagellates in the stratified Patapsco River estuary: Margalef reigns
}

\author{
K. G. Sellner ${ }^{1, *}$, S. G. Sellner ${ }^{2}$, R. V. Lacouture ${ }^{2}$, R. E. Magnien ${ }^{3}$ \\ ${ }^{1}$ Chesapeake Research Consortium, 645 Contees Wharf Road, Edgewater, Maryland 21037, USA \\ ${ }^{2}$ Academy of Natural Sciences, Estuarine Research Center, 10545 Mackall Road, St. Leonard, Maryland 20685, USA \\ ${ }^{3}$ Maryland Department of Natural Sciences, Tidewater Ecosystem Assessment, Tawes Office Building D-2, \\ 580 Taylor Avenue, Annapolis, Maryland 21401, USA
}

\begin{abstract}
Phytoplankton composition in the mesohaline Patapsco River estuary, a tributary of Chesapeake Bay, is dominated by dinoflagellates throughout the summer. This dominance is attributed to the nutrient-turbulence relationships that have been described by Margalef over the last $30 \mathrm{yr}$, a field verification of this highly respected theory. The partially stratified estuary is typified by ambient nutrient concentrations higher than those in any other mesohaline area of the northern bay and its tributaries. Mean dissolved inorganic nitrogen (DIN) and dissolved inorganic phosphorus (DIP) concentrations in surface waters of the stratified estuary exceed 30 and $0.5 \mu \mathrm{M}$, respectively, during the summer, and new and regenerated nutrient loadings ensure maintenance of these high levels through the productive growing season. Turbulence levels are suggested to be low in surface waters of the stratified water column, selecting for motile dinoflagellates throughout the summer. Dinoflagellate dominance in the Patapsco River estuary is further ensured through only minor grazing pressure from low rotifer demand and low standing stocks of ambient herbivorous copepod populations, the latter group being present at levels lower than in any other mesohaline system of the Chesapeake and its tributaries. The resulting high dinoflagellate biomass appears to support a large and active microheterotrophic community (microbial loop), exemplified by abundant rotifers, high oxygen demand, and high nutrient regeneration in the water column and sediments. From these traits, the dinoflagellate-dominated mesohaline Patapsco River estuary and the tidal-fresh cyanobacteria bloom areas of the upper Potomac River appear to be analogous, with salinity defining species composition of the phytoplankton.
\end{abstract}

KEY WORDS: Dinoflagellates $\cdot$ Nuisance algae $\cdot$ Nutrients $\cdot$ Turbulence $\cdot$ Stratification $\cdot$ Zooplankton $\cdot$ Ctenophores $\cdot$ Food web

Resale or republication not permitted without written consent of the publisher

\section{INTRODUCTION}

'Nuisance algae' often dominate stratified aquatic systems typified by high nutrient concentrations, with noxious blooms of cyanobacteria (blue-green algae) forming floating scums in many lakes, slow-moving rivers, and farm ponds. In brackish waters, 'nuisance algae' are most often dinoflagellates as low salinities

*E-mail: sellner@serc.si.edu pose problems for growth of generally halo-intolerant bloom-forming cyanobacteria common to freshwaters by limiting photosynthetic ability and buoyancy regulation (see Sellner et al. 1988). Persistent accumulations of autotrophic dinoflagellates would be expected in nutrient-rich, low-turbulence areas, as described by Margalef (1978).

The Chesapeake Bay and its tributaries are some of the most enriched coastal plain estuaries in North America, resulting in an aggressive multi-State and Federal effort to reduce nutrient loadings and produc- 
tivity in recent decades. By implementing rigorous point-source control strategies and encouraging best management practices in urban and agricultural communities, nutrient loads to many Chesapeake Bay tributaries have been reduced, particularly on the bay's western shore. In some cases, these nutrient reductions have lead to reductions in phytoplankton standing stocks, a first step towards reversing bay eutrophication that has been on-going since European settlement and has accelerated over the last half-century. However, some tributaries have such high loadings that even documented reductions in nutrient inputs still result in high nutrient levels downstream, potentially supporting high phytoplankton production and summer hypoxia/anoxia below the pycnocline in mesohaline areas. Such is the case for the lower Patapsco River estuary in northern Chesapeake Bay, the mesohaline estuary whose watershed includes urban Baltimore and its developed suburbs. Although nutrient loads to the system appear to have declined over an $18 \mathrm{yr}$ monitoring period (1984 to 2001), summer phytoplankton biomass and productivity still remain high, exceeding levels/rates measured in other, similar salinity systems in the watershed. This is probably a result of near optimal growth conditions for the brackishwater dinoflagellates which thrive in this system and are dominated by the motile group because of conditions consistent with the selection processes outlined by Margalef over the last $30 \mathrm{yr}$.

\section{METHODS}

As part of an 18 yr monitoring program (1984 to 2001) in the northern Chesapeake Bay, water quality and lower trophic level collections were made at 1 station in the shipping channel of the lower Patapsco River estuary, a major shipping port, with sampling throughout the productive spring-fall period. Data for 13 yr (1985 to 1997), have been analyzed to assess long-term changes in nutrient stocks and the plankton communities, as well as some components of the benthic recycling community. Water and biological samples were collected every 2 wk at Stn WT5.1 ( 15 m; $39^{\circ} 12^{\prime} 30^{\prime \prime} \mathrm{N}, 76^{\circ} 31^{\prime} 30^{\prime \prime} \mathrm{W}$ ) in the main shipping channel of the estuary (Fig. 1). Routine sampling included biological, chemical, and physical measurements. Vertical distributions of PAR were determined with a LiCor submersible sensor. Using a Beckman RS5-3 salinometer and YSI oxygen meter and, more recently, Scout 2 and Survey 2 Hydrolabs, vertical distributions of temperature, conductivity, salinity, and dissolved oxygen were determined through the water column. Water samples at discrete depths were subsequently collected using a small diaphragm pump, with in vivo fluorescence determined at each depth using a Turner Designs Flurometer. Chlorophyll a content at discrete depths was determined according to APHA (1985). For phytoplankton and microzooplankton, samples were combined from 5 depths above then 5 depths below

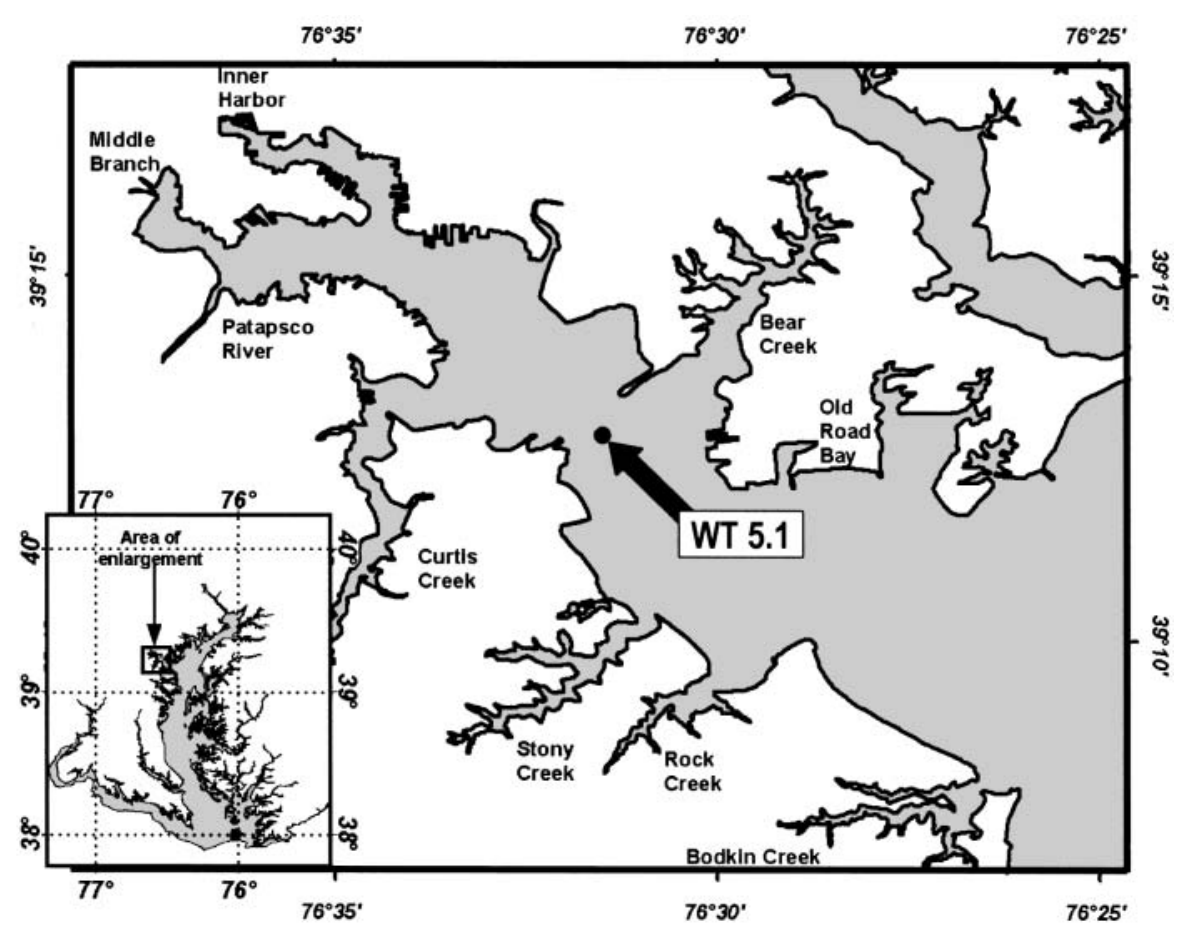

Fig. 1. Station WT5.1 in the Patapsco River estuary, a sub-estuary of Chesapeake Bay 
the pycnocline into 2 composite samples above and 2 below the pycnocline. Microzooplankton were concentrated in a submerged $44 \mu \mathrm{m}$ plankton net, then rinsed into a small jar with $5 \%$ buffered formaldehyde. Composite water samples were then gently mixed and water was decanted into $500 \mathrm{ml}$ bottles containing acid Lugol's solution for phytoplankton enumeration with a Leitz Diavert microscope at $312 \times$ and $500 \times$ total magnification. A minimum of $250>2 \mu \mathrm{m}$ cells were enumerated, and cell volume and cell carbon content were assigned from approximate geometric shapes and the formulas of Strathmann (1967) and Smayda (1978). Microzooplankton were identified at $100 \times$ and converted to biomass according to Brownlee \& Jacobs (1987). Additional subsamples from the surface composite samples were decanted into polycarbonate bottles, enriched with $\mathrm{NaH}^{14} \mathrm{CO}_{3}$, and incubated for $>1 \mathrm{~h}$ in a flow-through, water-cooled incubator with $\sim 200 \mu \mathrm{E} \mathrm{m} \mathrm{m}^{-2} \mathrm{~s}^{-1}$ from cool-white fluorescent lights. Daily fixation was then estimated according to Keefe et al. (1981). Mesozooplankton were collected using metered, stepped, oblique net $(202 \mu \mathrm{m})$ hauls through the water column. Ctenophores and medusae were poured off and volume estimated with a graduated cylinder, with the remainder of the plankton samples preserved in a Rose Bengal-5\% buffered formaldehyde solution.

Water samples were also retrieved from discrete depths for estimating inorganic and organic nutrient pools. Following filtration through Whatman GF/F filters, dissolved inorganic nitrogen (DIN) was determined as the sum of nitrate, nitrite, and ammonium (EPA 1979); dissolved inorganic phosphorus was also determined according to EPA (1979). Dissolved organic carbon (DOC) was determined following persulfate oxidation (Menzel and Vaccaro 1964). Flows for the Patapsco River and the main tributary to the Chesapeake Bay, the Susquehanna River, were obtained from the United States Geological Survey.

\section{RESULTS}

Ambient nutrient concentrations in Baltimore Harbor for the July to September period, 1985 to 1997 , were very high. Mean $( \pm \mathrm{SE})$ summer concentrations of DIN and DIP in the surface mixed layer were $32.8 \pm 4.4$ and $0.5 \pm 0.1 \mu \mathrm{M}$, respectively; for comparison, concentrations of DIN were 3 to 7 times higher than those observed in 4 other mesohaline regions of the study area (Table 1). DIN declined through time in the system, and similarly DIP declined for the first $7 \mathrm{yr}$, then fluctuated widely (Fig. 2). The high nitrogen concentrations in the estuary resulted in very high summer N/P ratios, exceeding 90 for the 1987 to 1991 period, and then fluctuating between $>20$ and 60 for the other years (Fig. 2).

Nutrient concentrations and phytoplankton biomass (as dinoflagellates) were related to open bay flow patterns dominated by the Susquehanna River discharge at the head of the bay. Nutrient concentrations as well

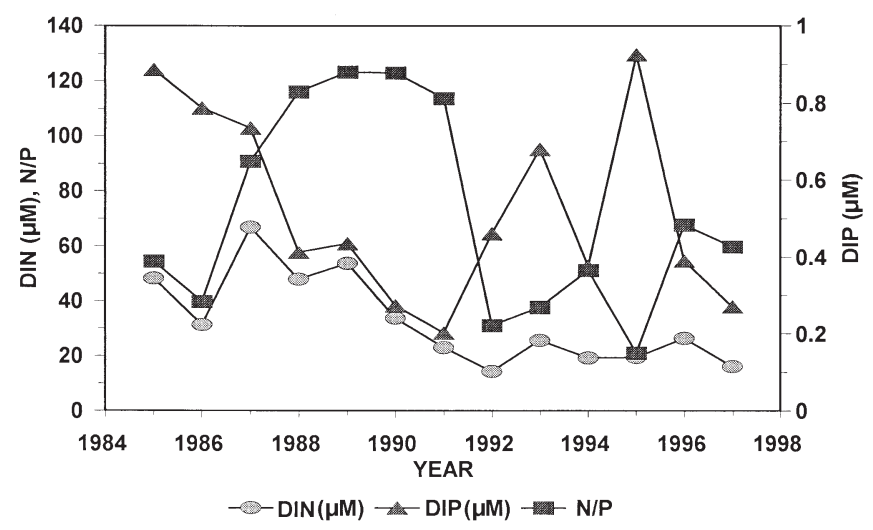

Fig. 2. Summer mean DIN and DIP concentrations $(\mu \mathrm{M})$ and N/P (at.) in the lower Patapsco River estuary for the period 1985 to 1997

Table 1. Comparison of nutrients and several plankton parameters (means \pm SE) for 5 mesohaline regions of the Chesapeake Bay and its tributaries, July to September, 1985 to 1997. DIN, DIP: dissolved inorganic nitrogen and phosphorus, respectively ( $\mu M)$, for the surface mixed layer. CHL: chlorophyll mean concentration in the surface mixed layer $\left(\mu g \mathrm{l}^{-1}\right)$; Dino-C: mean surface mixed-layer biomass (C) of dinoflagellates. Biomass data for Dino-C, rotifers, and adult copepods is presented as $\mu \mathrm{C} C \mathrm{l}^{-1}$. Ctenophores (Ctenos) data are presented as $\mathrm{ml} \mathrm{m}^{-3}$. For the study period, dissolved silicate and dissolved biogenic silicate levels in the surface mixed layer of the Patapsco estuary station were $54.1 \pm 3.3$ and $9.2 \pm 0.6 \mu \mathrm{M}$, respectively

\begin{tabular}{|c|c|c|c|c|c|c|c|}
\hline Region & DIN & DIP & CHL & Dino-C & Rotifers & Copepods & Ctenos \\
\hline Patapsco & $32.8 \pm 4.4$ & $0.5 \pm 0.1$ & $48.6 \pm 8.2$ & $1353 \pm 455$ & $45.1 \pm 6.3$ & $38.2 \pm 6.1$ & $14.5 \pm 2.9$ \\
\hline Patuxent & $6.8 \pm 1.1$ & $1.1 \pm 0.1$ & $25.3 \pm 3.7$ & $596 \pm 113$ & $24.9 \pm 4.9$ & $76.9 \pm 8.6$ & $11.3 \pm 5.6$ \\
\hline Potomac & $5.7 \pm 0.6$ & $2.5 \pm 0.3$ & $17.5 \pm 2.2$ & $763 \pm 223$ & $18.5 \pm 3.2$ & $43.5 \pm 5.7$ & $8.7 \pm 3.9$ \\
\hline Choptank & $9.0 \pm 1.2$ & $1.5 \pm 0.3$ & $36.2 \pm 3.4$ & $231 \pm 31$ & $16.5 \pm 2.3$ & $89.9 \pm 14.5$ & $18.8 \pm 7.2$ \\
\hline Chesapeake Bay & $4.5 \pm 1.3$ & $0.7 \pm 0.0$ & $8.7 \pm 0.7$ & $207 \pm 46$ & $3.5 \pm 1.1$ & $52.7 \pm 10.0$ & $11.5 \pm 3.2$ \\
\hline
\end{tabular}



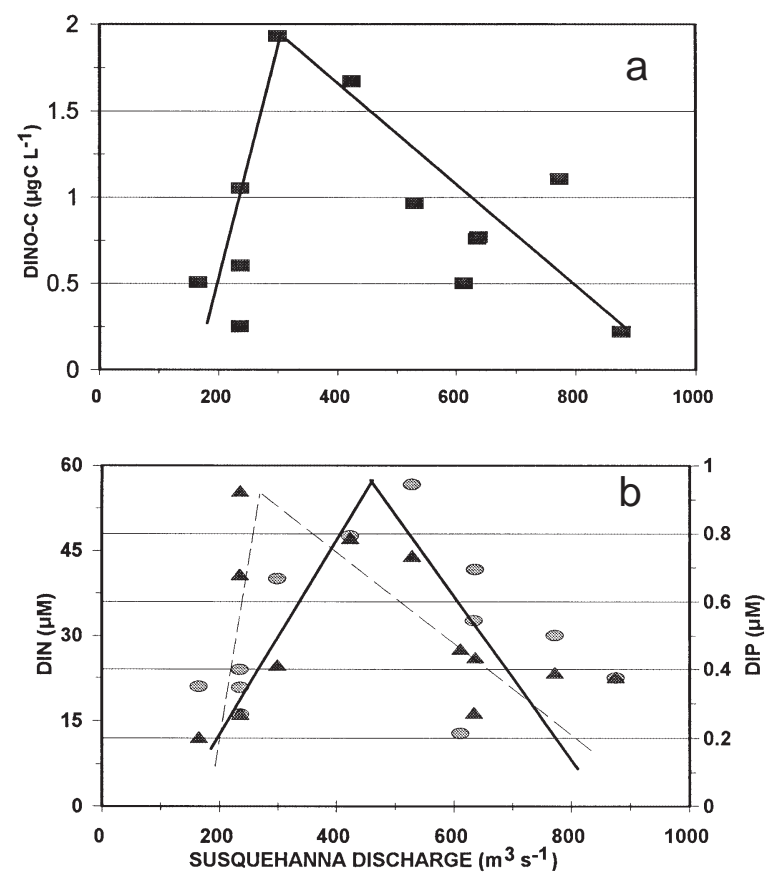

Fig. 3. Relationships between Susquehanna River discharge and (a) mean summer dinoflagellate biomass, and (b) DIN and DIP) in the lower Patsapsco River estuary, 1986 to 1997 (1985 data excluded due to extremely high dinoflagellate biomass of $7 \mathrm{mgC}^{-1}$ ). Lines have been added to visually assist identifying the increasing and decreasing trends of the 3 parameters

as dinoflagellate biomass increased as Susquehanna discharge increased from approximately $<200$ to $450 \mathrm{~m}^{3} \mathrm{~s}^{-1}$ (Fig. 3). However, at higher flows, DIN, DIP, and dinoflagellate biomass decreased, with DIP and dinoflagellate biomass falling off at lower flows than observed for DIN.

Phytoplankton biomass was high in the estuary over the entire period, ranging from $>7200 \mu \mathrm{gC}^{-1}$ in 1985 to a minimum of $400 \mu \mathrm{gC} \mathrm{l}^{-1}$ in 1993 (Fig. 4). The community was dominated by autotrophic, non-toxic dinoflagellates, with $>85 \%$ of the phytoplankton assemblage comprised of dinoflagellates in 1985; the mean contributions of this group to the entire assemblage approximated $61 \%$ for the $13 \mathrm{yr}$ period. The primary contributors to the dinoflagellates were Prorocentrum minimum, Gymnodinium spp., Heterocapsa rotundata (= Katodinium rotundatum), and Scrippsiella trochoidea. Temporal dynamics of the dinoflagellates were not, however, uniquely different from those of other autotrophic eucaryotes in the system, as dinoflagellate and total autotrophic eucaryote biomass followed similar patterns through the study period (Fig. 4).

There were no strong relationships observed between either of the nutrient pools and dinoflagellate

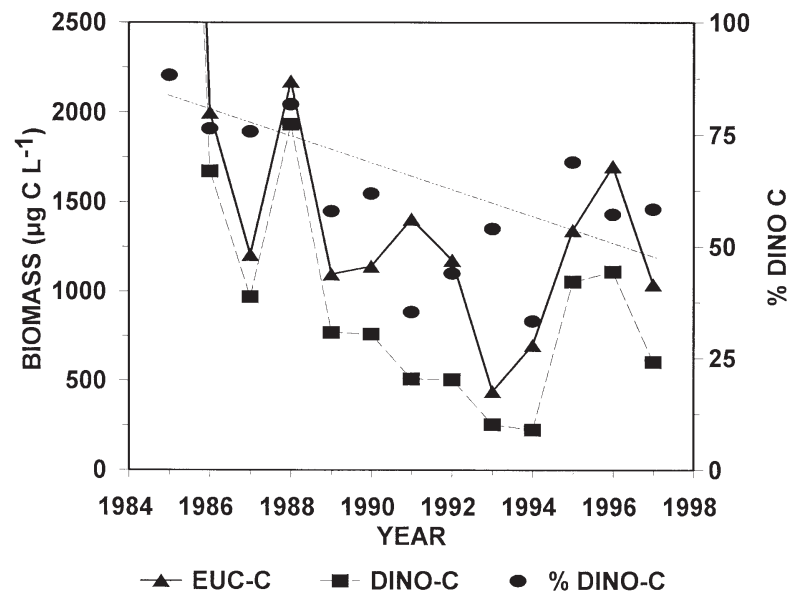

Fig. 4. Temporal distribution of mean summer $>2 \mu \mathrm{m}$ eucaryote $(\boldsymbol{\Lambda})$ and dinoflagellate $(\boldsymbol{\square})$ biomass and the relative contribution of dinoflagellates $(\%, \bullet$; dot-dashed line represents approximate change through time) to the $>2 \mu \mathrm{m}$ eucaryote assemblage in the lower Patapsco River estuary, 1985 to 1997

biomass. Of the 3 nutrient parameters (summer DIN, DIP, and N/P) DIN levels were most strongly related to dinoflagellate biomass, but still only weakly $\left(\mathrm{r}^{2}=0.18\right.$, $\mathrm{p}<0.18$ ), even with the apparent linkage between DIN, dinoflagellates, and Susquehanna flow in Fig. 3. The were no relationships between DIP and dinoflagellate biomass $\left(r^{2}=0.09, p>>0.5\right)$ nor N/P to dinoflagellate biomass $\left(r^{2}<0.001, p>>0.5\right)$ over the study period.

The high phytoplankton biomass observed in the system supported a large rotifer assemblage, with rotifer biomass higher than that observed in any other mesohaline station in Chesapeake Bay or its tributaries (Table 1). Rotifers in the $>44 \mu \mathrm{m}$ fraction, primarily Synchaeta spp., were very abundant, resulting in an average summer biomass approximating $45 \mu \mathrm{gC} \mathrm{l}^{-1}$, levels 2 to 15 times greater than those observed at 4 other mesohaline stations sampled in the program (Fig. 5, Table 1).

The primary planktonic herbivores in Chesapeake Bay in summer, adult and copepodite Acartia tonsa, were not well represented in the Patapsco estuary. Mean biomass approximated $38 \mu \mathrm{gC}^{-1}$ ( 6 adults), the lowest of any mesohaline station in the Chesapeake region (Fig. 5, Table 1), possibly attributed to ctenophore grazing associated with a summer population approximating $14.5 \mathrm{ml}$ ctenophores $\mathrm{m}^{-3}$ on average (>46 ml m $\mathrm{m}^{-3}$ in 1997).

\section{DISCUSSION}

A summary of the results leads to the following conclusion, that field conditions of the Patapsco River estu- 
ary, specifically high nutrient concentrations and supplies in a stratified water column, low turbulence, and minimal herbivory, select for autotrophic dinoflagellates in this system. This may be the best, or only, field example of Margalef's (1978) theoretical nutrientturbulence relationship and the selection of dinoflagellates in situ.

Justification for this conclusion must cover the components of Margalef's paradigm, and nutrients are addressed first. Unlike the majority of mesohaline reaches in the Chesapeake Bay and its tributaries, inorganic nutrient concentrations in the lower Patapsco River estuary during summer were extremely high. The levels of $32 \mu \mathrm{M}$ DIN in the estuary were approximately 4 to 5 times the concentrations observed in 4 other mesohaline stations, and far above any levels ( 0.5 to $1 \mu \mathrm{M}$ ) that could limit nitrogen uptake or growth (see Fisher et al. 1988). Similarly, DIP concentrations of $0.5 \mu \mathrm{M}$ exceeded limiting concentrations previously reported (Fisher et al. 1988) by about 5-fold. Further, P limitation in situ (suggested by the high N/P and previous results in Fisher et al. 1999), would not be manifested as pools, and recycling (see below) probably provides sufficient $\mathrm{P}$ for dinoflagellate demands. (Fisher et al.'s results were derived from short-term bioassays at the station, and in 12 of 26 experiments P limitation was detected for the period February 1989 to December 1994. However, P limitation was only observed in non-summer months, consistent with the conclusion above, i.e. that ambient $\mathrm{P}$ availability during summer never limits phytoplankton growth.) Therefore the high ambient nutrient levels suggest that nutrient-limited growth in this system would be rarely observed in situ.

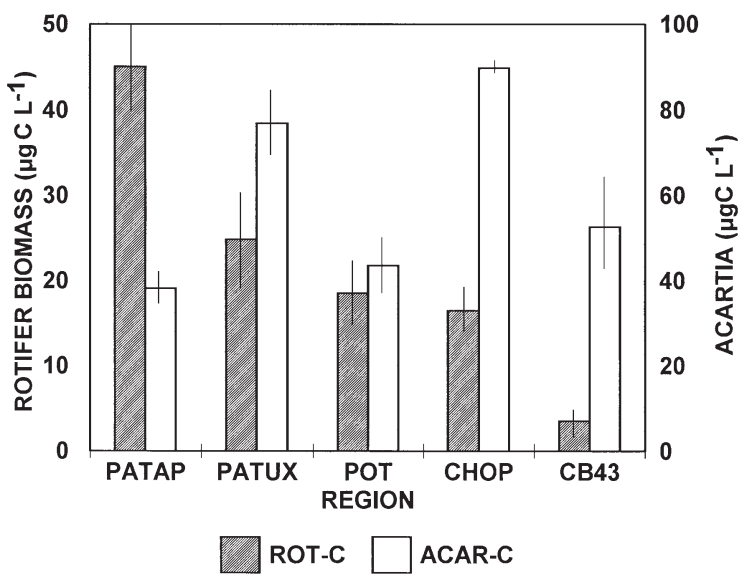

Fig. 5. Mean summer biomass of $>44 \mu \mathrm{m}$ rotifers (ROT-C) and Acartia tonsa (ACAR-C) copepodites and adults in the Patapsco River estuary (PATAP) and 4 other mesohaline stations in the Patuxent (PATUX), Potomac (POT), Choptank (CHOP), and main channel of Chesapeake Bay (CB43), 1985 to 1997. Vertical bars represent standard errors
Nutrient concentrations in the Patapsco River estuary were a function of at least 3 mechanisms, with the largest from local inputs from urban Baltimore and its suburbs. Although detailed accounting of loads is not available on an annual basis, total 1996 loads from local watersheds, primarily from industry and sewage treatment plants (79\% as point-source inputs), approximated 5.62 and $0.23 \times 10^{6} \mathrm{~kg} \mathrm{~N}$ and $\mathrm{P}$, respectively, annually. After correcting for volume of the estuary, this equates to 2.44 and $0.04 \mu \mathrm{M} \mathrm{N}$ and $\mathrm{P} \mathrm{d}^{-1}$ for the system. Estimates in 1985 were higher still, suggesting elevated nutrient inputs throughout the study period, even with progressive reductions from 1985 to 1996.

Nutrient regeneration also contributes to total nutrient availability in the system, particularly during the high-temperature conditions of the summer season. Weaver et al. (1995a,b) and Boynton et al. (1997) reported summer DIN flux, primarily as ammonium, from the sediments around the harbor, and although no measurements were made directly beneath the plankton station, the mean flux rates for 3 summers was $883 \mu \mathrm{M} \mathrm{m}^{-2} \mathrm{~h}^{-1}$ (obtained from averaging maximum and minimum rates). For DIP in the same study, the rate was $54 \mu \mathrm{M} \mathrm{m}^{-2} \mathrm{~h}^{-1}$ and, assuming a $24 \mathrm{~h}$ day, these fluxes would contribute approximately $1.4 \mu \mathrm{M}$ DIN and $0.09 \mu \mathrm{M}$ DIP to the overlying water column each day. These benthic fluxes are 2 to 4 times and 1.8 to 10 times higher, respectively, than for similar salinity stations studied elsewhere (Weaver et al. 1995a,b, Boynton et al. 1997).

Although no bacterial measurements or oxygen fluxes are available for the Patapsco water column, nutrient supply from water column recycling should also be high. As recently argued by del Giorgio et al. (1997), bacterial respiration should approximate $34 \%$ of net primary productivity of the lower Patapsco River estuary and, assuming $\mathrm{N}$ and $\mathrm{P}$ recycling during respiration follows the Redfield ratio, at summer productivities exceeding $2.2 \mathrm{gC} \mathrm{m}^{-2} \mathrm{~d}^{-1}$, total $\mathrm{N}$ and $\mathrm{P}$ remineralization from bacterial catabolism alone would approximate 9.3 and $0.6 \mathrm{mM} \mathrm{m}^{-2} \mathrm{~d}^{-1}$, respectively, or approximately 0.62 and $0.04 \mu \mathrm{M}$ each day - a large and continuous supply of autochthonous nutrient in the $15 \mathrm{~m}$ water column.

A slight aside: These high rates emphasize the importance of microheterotrophic metabolism (the microbial loop) in the estuary, further supported by the high biomass of pico- and microplankton-grazing rotifiers observed in the system (Table 1). Additionally, hypoxia typified bottom waters from July into September, with occasional anoxia as well, indicating high oxygen consumption and additional support for an active bacterial community. Organic substrates, fueling bacterial metabolsim, were also high, approximating $2.9 \pm 0.3 \mathrm{mg} \mathrm{DOC}^{-1}$ for the period; this is not sur- 
prising considering the high overall phytoplankton biomass of the system as well as the large point-source loads from local sewage plants.

The large point-source inputs and high internal recycling rates (the sum of sediment flux and estimated water column recycling) producing 4.5 and $0.17 \mu \mathrm{M} \mathrm{d}^{-1}$ $\mathrm{N}$ and $\mathrm{P}$, respectively, probably explain why only modest relationships were observed between ambient DIN levels and dinoflagellates. That is, nutrient loads are so rapid and high that singling out a relationship between primary producers and ambient pools would be difficult. The close correlation between Susquehanna River flow and DIN (and DIP) levels in the Patapsco, particularly evident at flows up to $450 \mathrm{~m}^{3} \mathrm{~s}^{-1}$ (see Fig. 3), probably reflects the 3-layer flow common to the Patapsco estuary (Olson et al. 1982), whereby low flows from local watersheds are more or less trapped in the estuary by only modest Susquehanna flow at the surface and bottom. This would lead to long residence time and dinoflagellate growth in high ambient nutrient stocks. As the Susquehanna flow increases, resulting in higher flows from the bay into the estuary at the surface and bottom, conservation of mass would force estuarine waters out, leading to a dilution of Patapsco nutrients and accumulated dinoflagellate biomass. This dilution is indicated in the decreasing DIN, DIP, and dinoflagellate biomass during Susquehanna discharges exceeding $450 \mathrm{~m}^{3} \mathrm{~s}^{-1}$ in Fig. 3 .

The high nutrient concentrations in the stratified Patapsco estuary provide near-optimal growth conditions for motile autotrophic (chlorophyll-rich) dinoflagellates. As outlined by Margalef in a series of papers over the last $30 \mathrm{yr}$, culminating in his most recent publication (Margalef 1997), the Patapsco nutrient levels coupled with stratification and low turbulence (see below) in the surface mixed layer of the enclosed estuary should have selected for dinoflagellates over diatoms during the $13 \mathrm{yr}$ study. First, motility and positive phototaxis ensure abundant light for the autotrophic dinoflagellates, unlike their water column partners, the non-motile diatoms. Second, the high nutrient stocks and supply rates provide the relatively poorly competing dinoflagellates (high half-saturation constants for uptake and growth) with a better opportunity to compete against other more nutrient-efficient phytoplankton. Third, if required, the presence of high nutrient reservoirs at depth could be readily accessed by diel migrations of the dinoflagellates (e.g., Cullen et al. 1985), ensuring a continuous nutrient supply.

Although not explicitly studied in the present sampling regime, another 'bottom-up' control could conceivably favor dinoflagellate dominance: elevated metal levels which could reduce ambient diatom densities and species. The Patapsco estuary is surrounded by large industries, discharging many toxic metals into the system, resulting in this system being characterized as a toxic 'hot spot' in the northern Chesapeake Bay. However, demonstrable impacts on the estuarine biota appear to be restricted to fauna associated with the sediment, with little apparent impact on the overlying phytoplankton assemblage. The apparent lack of impact in the water column is likely to be due to metal concentrations that have not been shown to have a demonstrable influence on phytoplankton growth. For example, dissolved copper, cadmium, and arsenic in early summer 1992 were $1.74,0.054$, and $1.17 \mu \mathrm{g} \mathrm{l}^{-1}$, respectively, in the surface water (Riedel et al. 1999), i.e. below levels believed to begin to alter growth and phytoplankton speciation (G. F. Riedel pers. comm.). Field free-ion concentrations for copper were also low, between 0.5 to $8 \mathrm{pM}$ for August (Donat 1994), i.e. below levels previously shown to reduce growth in several coastal phytoplankton species (Brand et al. 1986). In recent experiments at our laboratory, copper levels had to exceed $5 \mathrm{\mu g} \mathrm{l}^{-1}$ for any diatoms to begin to decline in multi-species experiments, mimicking fieldenclosure results from CEPEX in western Canada in the 1970s (Harrison et al. 1977, Thomas \& Seibert 1977). For arsenic, levels $>1.2 \mathrm{\mu g} \mathrm{l}^{-1}$ only begin to alter diatom species when phosphorus concentrations are limiting (S. Rikke \& J. G. Sanders unpubl. data) and as the phosphorous concentrations and supply are very high in the Patapsco system (see above), an arsenic effect is unlikely. There have been no demonstrable effects of cadmium on phytoplankton at any levels approaching those levels in the Patapsco. Donat (1994) reported free cadmium ion concentrations in August near the estuary at 0.9 to $20 \mathrm{pM}$, again below levels that Brand et al. (1986) showed would reduce division rates of coastal phytoplankton populations. So although high industry density around the Patapsco estuary encourages speculation on metal-induced toxicity of the normally dominant diatom assemblages, there are no data supporting selective inhibition of the diatoms for the benefit and accumulation of dinoflagellates.

A fourth reason for dinoflagellate dominance is low grazing pressure (low top-down control) from rotifers, and only modest levels of copepods in the system (Table 1). The net effect would be to reduce mortality of all phytoplankton and, as the dominant populations, the release from grazing pressure would only further the success of the motile dinoflagellates. Rotifers, as several of the largest members of the microzooplankton, feed on small phytoplankton and bacteria. The Patapsco dominant, Synchaeta sp., has been observed gorged with the dinoflagellate Prorocentrum minimum in several mesocosm samples collected at our laboratory, and feeding on Gymnodinium pseudopalustre in the lower Potomac River estuary (Tyler \& Heinbokel 1985). For the abundant rotifers of the Patapsco, a diet 
consisting of dinoflagellates alone would account for only a trivial amount of ambient dinoflagellate stocks. Using Tyler \& Heinbokel's ingestion rates of 2 cells rotifer $^{-1} \mathrm{~h}^{-1}$ for Synchaeta sp. in the lower Potomac River estuary in a G. pseudopalustre bloom, its total demand would be $<3 \times 10^{4}$ cells $\mathrm{l}^{-1} \mathrm{~d}^{-1}$, far less than $1 \%$ of the ambient concentrations of dinoflagellates present during the summer. There was no correlation between dinoflagellate densities and rotifers for the Patapsco system $\left(r^{2}=0.02\right)$.

Selective grazing of rotifers on other phytoplankton groups might also depress 1 group and allow expression of another, such as dinoflagellates. Dolan \& Gallegos $(1991,1992)$ previously identified an inverse relationship between rotifers and microflagellates in the Rhode River estuary just to the south of the Patapsco system. However, no such pattern was observed in the present study $\left(r^{2}=0.02\right)$. Further, using Dolan \& Galle-

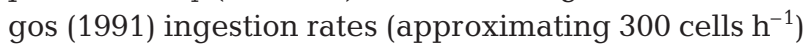
and assuming solely microflagellates as prey, Patapsco rotifer populations would remove about one-third of the estimated daily microflagellate production in the system. Considering the diverse assemblage of potential prey in the Patapsco estuary, with enumerated phytoplankton ranging from several to ten million cells per liter, non-enumerated heterotrophic flagellates at $10^{7} \mathrm{ml}^{-1}$ (e.g., Dolan \& Gallegos 1991), <30 $\mu$ m ciliates at $10^{4-5} \mathrm{l}^{-1}$ (Coats \& Revelante 1999), and bacteria at $10^{6-7} \mathrm{ml}^{-1}$ (e.g., Shiah \& Ducklow 1994), it is unlikely that rotifer grazing would selectively remove sufficient autotrophic microflagellates to free dinoflagellates from predation; there is more than enough food, dinoflagellates included, for the ambient rotifer assemblage. More succinctly, dinoflagellate dominance was not likely to have been a result of growth and accumulation as a result of selective predation on other autotrophic members of the phytoplankton.

Copepods, the other primary herbivores, apparently also exerted little pressure on the dinoflagellates. Low copepod biomass (Table 1), equivalent to approximately 6 adults $\mathrm{l}^{-1}$ on average, is likely ensured through top-down control by ctenophores (Mnemiopsis leidyi in the Chesapeake Bay system) or alternatively through some other mechanism that might reduce copepod 'success' (e.g., toxicant-reduced fecundity [Sunda et al. 1990] or poor food quality impacts on growth, [Dam et al. 1999]). Ctenophore grazing of Acartia tonsa probably removed substantial numbers of this copepod, as ctenophore levels over the study period $\left(14.5 \pm 2.9 \mathrm{ml} \mathrm{m}^{-3},>46 \mathrm{ml} \mathrm{m}^{-3}\right.$ in 1997) were the second highest levels observed for 5 mesohaline stations analyzed over the same period (Table 1).

An estimate of carnivory was derived to quantify actual ctenophore demand. As a bulk measurement of ctenophore volume has no individual organism charac- terization, it is difficult to quantify total ctenophore grazing pressure with any certainty. Therefore, the following assumptions were made. First, 2 extremes in the size distribution of Mnemiopsis leidyi were considered, one with all small individuals (5 ctenophores of approximately $3 \mathrm{ml}$ ) and a second with 2 large individuals ( 2 ctenophores of 7 to $8 \mathrm{ml}$ ). After converting volume to wet weight (Kremer \& Nixon 1976), clearance rates were estimated after Purcell et al. (2001). With these assumptions, ctenophores in the Patapsco estuary would have removed an average of 7 to $10 \% \mathrm{~d}^{-1}$ of the ambient copepod stocks over the study period, on the high side of the ctenophore-induced losses reported for mid-Chesapeake Bay in 1988 (Purcell et al. 1994); in 1997, making the same size-distribution assumptions, 22 to $32 \%$ of ambient stocks would have been removed.

Other characteristics of this urban estuary might conceivably further reduce copepod reproductive success. There are some data from the Patapsco estuary suggesting that copepods may experience toxicity from exposure to high toxicant levels of the sediments, and (with fewer observations), from dissolved watercolumn compounds. In an intensive study of Patapsco estuary sediment toxicities, McGee et al. (1999) reported zinc concentrations of up to $35 \mathrm{nmol} \mathrm{g}^{-1}$ dry wt sediment, overlapping water-column dissolved levels reported to reduce egg-laying and nauplii survival in Acartia tonsa (Sunda et al. 1987, 1990). Other components of the sediments might also impact $A$. tonsa as observed for the benthic amphipod Leptocheirus plumulosus (McGee et al. 1999): toxic levels of chromium, nickel, lead, copper, zinc, mercury, and selected polyaromatic hydrocarbons recorded for the amphipod might conceivably impact nauplii and adult A. tonsa as well, and perhaps reduce egg-hatching success once the eggs sank to the bottom. Using the winter-spring dominant copepod in Chesapeake Bay, Eurytemora affinis, Hall et al. (1997) reported that in 4 of 6 exposures to ambient water (October), the mean percent immature stages (nauplii and copepodites) were $0,0,0$, and $1.6 \pm 1.6 \%$ following an $8 \mathrm{~d}$ exposure; controls yielded $6.8 \pm 2.5 \%$, suggesting some possibility of toxicity in the system. However, only 1 sample in the estuary exceeded the acute-water quality criteria of the US Environmental Protection Agency for copper, and although the analysis was for total dissolved copper and not cupric ion activity, the results could suggest some toxicity to the ambient copepods from this element. Although mortality was not reported in the Hall et al. study, Sunda et al. (1987) recorded reduced copepod survival (adult and nauplii) when free cupric ion activities exceeded $10^{-10}$ to $10^{-11} \mathrm{M}$. Considering Donat's (1994) report of 0.5 to $8 \mathrm{pM}$ free cupric ion in the water column in August 1992, any toxicity would 
be expected to apply to sediments only. Overall, sediment pollutant levels might reduce copepod success through interference with egg-hatching and early lifestage development, while impacts from potentially toxic materials in the overlying waters appear less likely.

A fifth, probably the most important parameter, turbulence in the estuary, is also likely to be of the proper magnitude for dinoflagellate dominance in this system. Margalef (1978) proposed that dinoflagellates would dominate in water columns typified by low turbulence, represented by the coefficient of eddy diffusion $K_{\mathrm{z}}$ at values of 0.02 to $1 \mathrm{~cm}^{2} \mathrm{~s}^{-1}$, while diatoms would be favored at $K_{\mathrm{z}}$ levels of 2 to $100 \mathrm{~cm}^{2} \mathrm{~s}^{-1}$. Another measure, $\varepsilon$, turbulent energy dissipation, has also been explored in phytoplankton succession (Peters \& Marrasé, in Estrada \& Berdalet 1998). At values exceeding $0.1 \mathrm{~cm}^{2} \mathrm{~s}^{-3}$, dinoflagellate growth rates decline whereas growth rates of other phytoplankton remain unaffected. Recent observations in natural systems indicate the importance of turbulence in selection of phytoplankton taxa, specifically dinoflagellates at low turbulence levels. In a study in Lake Kinneret, Berman \& Shteinman (1998) attributed the prevalence of Peridinium gatunense blooms to very low levels of turbulent kinetic energy (TKE), with bloom intensity inversely related to TKE over a 5 yr period.

Although no direct measurements of turbulence have been obtained for the Patapsco Rivery estuary, it is highly likely that low turbulence typifies surface waters of the stratified system and might be represented by measurements made for other portions of the Chesapeake and its tributaries. Suttles et al. (1999) reported a $K_{\mathrm{z}}$ for turbulent mixing in an open Chesapeake Bay station ranging from 0.001 to $>1 \mathrm{~cm}^{2} \mathrm{~s}^{-1}$,

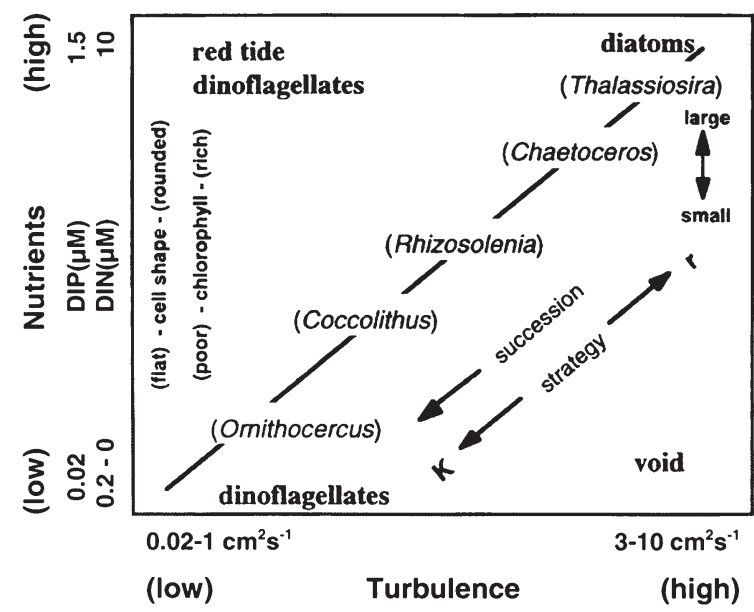

Fig. 6. Phytoplankton succession as a function of turbulence and nutrient concentrations (from Margalef 1978, 1997). High nutrient concentrations, stratification, and low turbulence select for the chlorophyll-rich dinoflagellates noted in the upper left corner of the figure with the lowest values in the water column interior and pycnocline and highest values near the surface and bottom. Similarly, $\varepsilon$ was $0.034 \mathrm{~cm}^{2} \mathrm{~s}^{-3}$ in surface waters of the Pocomoke River estuary, below the $0.1 \mathrm{~cm}^{2} \mathrm{~s}^{-3}$ cut-off for inhibition of dinoflagellate growth. Assuming that something close to these rates is applicable to the stratified lower Patapsco, then turbulence is well within the range of minimal levels that select for dinoflagellates when nutrients are excessive (Fig. 6), and this estuary represents one of the few field situations where high nutrients, low turbulence, and minimal top-down grazing pressure are likely to provide near optimal conditions for the overwhelming dominance of bloom-forming dinoflagellate populations. Changing a single parameter, e.g., increasing turbulence in the surface mixed layer, should select for diatoms and not dinoflagellates in the Patapsco estuary, certainly a testable hypothesis for future focused research in the system.

That the Patapsco River estuary is dramatically different from other mesohaline areas of the watershed is not surprising (Table 1) considering the large pointsource inputs and regeneration in this system compared to the other areas. The Patapsco receives primarily urban discharge from Baltimore, a city of 1 million with a highly developed local industry around the harbor. In contrast, the other mesohaline reaches are primarily in more rural areas, with little point-source discharge in their immediate vicinity. Additionally, the other areas are open to Chesapeake Bay and meteorological events, so direct bay influence, mixing, and lower nutrient-loading prevents excessive algal accumulation, particularly on-going, persistent dominance by dinoflagellates. Based on the information amassed in this study, it is suggested that minimal turbulence in the enclosed, nutrient-rich Patapsco estuary provides near optimal conditions for dinoflagellate growth.

Finally, there are remarkable similarities between conditions favoring dinoflagellates in the brackish Patapsco River estuary and those associated with cyanobacteria blooms in tidal freshwater of the Potomac River estuary, another Chesapeake Bay tributary. The former represents a phytoplankton response to excessive nutrient loads and availability in a brackish environment, while the latter is characteristic of nutrientreplete, quiescent freshwater systems. Specifically, the tidal freshwater Potomac has very high nutrient levels (Boynton et al. 1995) and the tidal river is large and deep so that it acts as a large lake, permitting buoyant cyanobacteria accumulation at its surface. There is minimal zooplankton herbivory (Sellner et al. 1993), and there is a constant source of nutrients from sewerage plant discharges immediately above the bloom site (Jaworski 1981) as well as phosphorus efflux from local 
sediments that increases with bloom-induced elevated $\mathrm{pH}$ in the overlying waters (Seitzinger 1991) . The differences in 'nuisance algae' between the Patapsco and Potomac systems reflect tolerances to salt. In both cases the excessive biomass of the nuisance taxa selects for microbial-loop-dominated metabolism, diverting energy from harvestable species to water-column oxygen demand, which in turn results in the increasingly frequent and longer-duration hypoxic and anoxic events observed in many of our coastal ecosystems.

Acknowledgements. The authors are indebted to a large number of field staff that have worked in the MD Water Quality and Plankton Monitoring Programs since its inception in 1984. The first author (K.S.) extends his gratitude to K. Braun, J. Gronefeld, A. Hartsig, S. Hedrick, A. Imirie, R. Jacobson, R. Matos, B. Michael, D. Nicholson, C. Parrish, A. Tate, B. Wagoner, C. Watson, W. Yates, R. Bahner, W. Boynton, E. Ebersole, T. Fisher, S. Gunsalus, A. Gustafson, L. Hall, R. Karrh, M. Marsh, R. Mason, M. Olson, F. Rohland, L. Sanford, S. Suttles, USGS, M. Suddleson, F. Younger, the captains and crews of the University of Maryland fleet and Maryland's RV 'Discovery' and the Maryland Water Quality field teams. K.S. also respectfully acknowledges assistance of M. Suddleson for some graphics, and funding provided by The Academy of Natural Sciences, Maryland Department of Natural Resources, Maryland Department of the Environment, and Maryland Department of Health and Mental Hygiene. Data sets are available from the Chesapeake Bay Program Office, Severn Street, Annapolis, Maryland, USA.

\section{LITERATURE CITED}

APHA (American Public Health Association) (1981) Method 1002 G, chlorophyll. In: Standard methods for the examination of water and wastewater, 16th edn. APHA, Washington, DC, p 1067-1070

Berman T, Shteinman B (1998) Phytoplankton development and turbulent mixing in Lake Kinneret (1992-1996). J Plankton Res 20:709-726

Boynton WR, Garber JH, Summers R, Kemp WM (1995) Inputs, transformations, and transport of nitrogen and phosphorus in Chesapeake Bay and selected tributaries. Estuaries 18:285-314

Boynton WR, Barnes JM, Rohland FM, Matteson LL, Magdeburger LL, Hagy III JD, Frank JM, Sweeney BF, Weir MM, Stankelis RM (1997) Ecosystem processes component level 1. Interpretive report No. 14. Chesapeake Biological Laboratory (CBL), University of Maryland System, Solomons, MD 20688-0038 (UMCEES CBL Ref. No. 97-009a)

Brand LE, Sunda WG, Guillard RRL (1986) Reduction of marine phytoplankton reproduction rates by copper and cadmium. J Exp Mar Biol Ecol 96:225-250

Brownlee DC, Jacobs F (1987) Mesozooplankton and microzooplankton in the Chesapeake Bay. In: Majumdar SK, Hall LW Jr, Austin HM (eds) Contaminant problems and management of living Chesapeake Bay resources, Pennsylvania Academy of Science, Philadelphia, PA, p 217-269

Coats, DW, Revelante N (1999) Distributional patterns and trophic implications of microzooplankton in the northern Adriatic Sea and Chesapeake Bay. In: Malone TC, Malej
A, Harding LW Jr, Smodlaka N, Turner RE (eds) Ecosystems at the land-sea margin: drainage basin to coastal sea. American Geophysical Union, Washington, DC, p 207-239

Cullen JJ, Zhu M, Davis R, Pierson DC (1985) Vertical migration, carbohydrate synthesis, and nocturnal nitrate uptake during growth of Cachonina niei in a laboratory water column. In: Anderson DM, White AW, Baden DG (eds) Toxic dinoflagellates. Elsevier, New York, p 184-194

Dam HG, Colin SP, Ledger J (1999) Effects of the dinoflagellate Prorocentrum minimum on feeding, fecundity, and egg hatching of the copepod Acartia tonsa. Aquatic Science Meeting, Santa Fe. American Society of Limnology \& Oceanography, Waco, TX, p 53 (abstract)

del Giorgio PA, Cole JJ, Cimbleris A (1997) Respiration rates in bacteria exceed phytoplankton production in unproductive aquatic systems. Nature 385:148-151

Dolan JR, Gallegos CC (1991) Trophic coupling of rotifers, microflagellates, and bacteria during fall months in the Rhode River estuary. Mar Ecol Prog Ser 77:147-156

Dolan JR, Gallegos CC (1992) Trophic role of planktonic rotifers in the Rhode River estuary, spring-summer 1991. Mar Ecol Prog Ser 85:187-199

Donat JR (1994) The speciation of dissolved copper and cadmium in Chesapeake Bay. EOS Trans, Am Geophys Un, 75(44):330 (Abstract)

EPA (US Environmental Protection Agency) (1979) Methods for chemical analysis of water and wastes. US Environmental Protection Agency, Cincinnati (EPA-600/4-79-020)

Estrada M, Berdalet E (1998) Effects of turbulence on phytoplankton. In: Anderson DM, Cembella AD, Hallegreaff GM (eds) Physiological ecology of harmful algal blooms. NATO ASI Ser, Ser G Ecol Sci 41:601-608

Fisher TR, Harding LW Jr, Stanley DW, Ward LG (1988) Phytoplankton, nutrients, and turbidity in the Chesapeake, Delaware, and Hudson estuaries. Estuar Coast Shelf Sci 15:621-644

Fisher TR, Gustafson AB, Sellner K, Lacouture R, Haas LW, Wetzel RL, Magnien R, Everitt D, Michaels B, Karrh R (1999) Spatial and temporal variation of resource limitation in Chesapeake Bay. Mar Biol 133:763-778

Hall LW Jr, Anderson RD, Killen WD, Scott MC, Kilian JV, Alden III RW, Adolphson P, Eskin RA (1997) Ambient toxicity testing in the Chesapeake Bay. Year 4 report. University of Maryland, Wye Research Education Center, Queenstown, MD

Harrison WG, Eppley RW, Renger EH (1977) Phytoplankton nitrogen metabolism, nitrogen budgets, and observations on copper toxicity: controlled ecosystem pollution experiment. Bull Mar Sci 27:44-57

Jaworski NA (1981) Sources of nutrients and the scale of eutrophication problems in estuaries. In: Neilson BJ, Cronin LE (eds) Estuaries and nutrients. Humana Press, Clifton, NJ, p 83-110

Keefe CW, Boynton WR, Kemp WM (1981) A review of phytoplankton processes in estuarine environments. University of Maryland, Solomons, MD (UMCEES Ref. 81-193 CBL)

Kremer JN, Nixon SW (1976) The distribution and abundance of the ctrenophore Mnemiopsis leidyi in Narragansett Bay. Estuar Coast Mar Sci 4:627-639

Margalef R (1978) Life-forms as survival alternatives in an unstable environment. Oceanolog Acta 1:493-509

Margalef R (1997) Our biosphere. Ecology Institute, Oldendorf/Luhe, Germany

McGee BL, Fisher DJ, Yonkos LT, Ziegler GP, Turley S (1999) Assessment of sediment contamination, acute toxicity, and population viability of the estuarine amphipod Lepto- 
cheirus plumulosus in Baltimore Harbor, Maryland, USA. Environ Toxicol Chem 18:2151-2160

Menzel DW, Vaccaro RF (1964) The measurement of dissolved and particulate carbon in seawater. Limnol Oceanogr 9:138-142

Olson P, Boicourt WC, Najarian TO (1982) A hydrodynamic study of the Baltimore Harbor system. II. A numerical model of the Baltimore Harbor circulation. Chesapeake Bay Inst., The Johns Hopkins University, Baltimore, MD (Ref. 82-11, Bull No. 2)

Purcell JE, White JR, Roman MR (1994) Predation by gelatinous zooplankton and resource limitation as potential controls of Acartia tonsa copepod populations in Chesapeake Bay. Limnol Oceanogr 39:263-278

Purcell JE, Shiganova TA, Decker MB, Houde ED (2001) The ctenophore Mnemiopsis in native and exotic habitats: US estuaries vs the Black Sea basin. Hydrobiologia (in press)

Riedel GF, Sanders JG, Osman RW (1999) Biogeochemical control on the flux of trace elements from estuarine sediments: effects of seasonal and short-term hypoxia. Mar Environ Res 47:349-372

Seitzinger SP (1991) The effect of $\mathrm{pH}$ on the release of phosphorus from Potomac estuary sediments: implications for blue-green algal blooms. Estuar Coast Shelf Sci 33: 409-418

Sellner KG, Lacouture RV, Parrish CR (1988) Effects of increasing salinity on a cyanobacteria bloom in the Potomac River estuary. J Plankton Res 10:49-61

Sellner KG, Brownlee DC, Bundy MH, Brownlee SG, Braun KR (1993) Zooplankton grazing in a Potomac River cyanobacteria bloom. Estuaries 16:859-872

Shiah FK, Ducklow HW (1994) Temperature and substrate regulation of bacterial abundance, production and specific growth rate in Chesapeake Bay, USA. Mar Ecol Prog Ser 103:297-308

Smayda TJ (1978) From phytoplankton to biomass. In:

Editorial responsibility: Otto Kinne (Editor),

Oldendorf/Luhe, Germany
Sournia A (ed) Phytoplankton manual. UNESCO, Paris, p 273-279

Strathmann RR (1967) Estimating the organic carbon content of phytoplankton from cell volume or plasma volume. Limnol Oceanogr 12:411-418

Sunda WG, Tester PA, Huntsman SA (1987) Effects of cupric and zinc ion activities on the survival and reproduction of marine copepods. Mar Biol 94:203-210

Sunda WG, Tester PA, Huntsman SA (1990) Toxicity of trace metals to Acartia tonsa in the Elizabeth River and southern Chesapeake Bay. Estuar Coast Shelf Sci 30:207-221

Suttles S, Sanford LP, Takasugi Y (1999) Field measurements of turbulence and turbulent mixing in Chesapeake Bay, USA. Fifteenth Biennial International Conference of the Estuarine Research Federation. Louisiana Sea Grant College, Baton Rouge, p 101 (Abstract)

Thomas WH, Seibert DLR (1997) Effects of copper on the dominance and diversity of algae: controlled ecosystem pollution experiment. Bull Mar Sci 27:23-33

Tyler MA, Heinbokel IF (1985) Cycles of red water and encystment of Gymnodium pseudopalustre in the Chesapeake Bay: effects of hydrography and grazing. In: Anderson DM, White AW, Baden DG (eds) Toxic dinoflagellates. Elsevier, New York, p 213-218

Weaver BJ, Boynton WR, Barnes JM, Magdeburger LL (1995a) Sediment-water oxygen and nutrient exchanges in the tidal Patapsco River/Baltimore Harbor and Back River tributaries. Chesapeake Biological Laboratory (CBL), University of Maryland System, Solomons, MD 20688-0038, USA (UMCEES CBL Ref. No. 95-062)

Weaver BJ, Boynton WR, Barnes JM, Magdeburger LL (1995b) Sediment-water oxygen and nutrient exchanges in the tidal Patapsco River/Baltimore Harbor and Back River tributaries. Chesapeake Biological Laboratory (CBL), University of Maryland System, Solomons, MD 20688-0038, USA (UMCEES CBL Ref. No. 95-170)

Submitted: June 30, 2000; Accepted: January 17, 2001

Proofs received from author(s): September 4, 2001 